\title{
Shoppers' perceptions of retail developments: Suburban shopping centres and night markets in Singapore
}

Received (in revised form): 21 August 2003

\section{Muhammad Faishal Ibrahim}

is an assistant professor in the Department of Real Estate, School of Design and Environment, National University of Singapore. Before joining the university he worked as a property valuer at the Inland Revenue Authority of Singapore. His areas of research include property valuation and behavioural real estate studies in the retail and residential property markets, and land transport issues.

\section{Soh Kok Leng}

graduated from the School of Design and Environment at the National University of Singapore with a degree in real estate. His research interests include issues pertinent to the impact of cultures and changing social trends on urban planning and urban landscapes.

\begin{abstract}
Over the last decade, pasar malam or night markets have been making their presence felt within the suburban public housing estates in Singapore. Similarly, suburban shopping centres have been sprouting up within public housing estates and situated next to mass rapid transit (MRT) and light rail transit (LRT) stations, bus stops and interchanges. Both pasar malam and suburban shopping centres belong to different components of the retail marketing system: the former belong to the bazaar sector while the latter belong to the firm-centred sector. In view of their differences, using a sequential mixed method approach involving a qualitative/quantitative sequence, this paper examines the different profiles of the shoppers and the link to their perceptions of different types of retail development. The findings suggest that property developers and retailers need to have a better understanding of their local markets in order to develop an appropriate 'experience'/product mix to cater for the shoppers within the catchment area.
\end{abstract}

\section{Keywords:}

perceptions, suburban shopping centres, night markets, Singapore, shoppers, demographics

\section{BACKGROUND}

The economies operating in the world can be generally classified into either firm-centred economies or bazaar economies. The firm- 


\section{Firm-centred and bazaar economies}

\section{McGee's three-stage model}

Night markets

\section{Suburban shopping centres}

centred economy is "where trade and industry occur through a set of impersonally defined social institutions which organise a variety of specialised occupations with respect to some particular production or distributive end'. ${ }^{1}$ The bazaar economy is one in which the total flow of commerce is fragmented into a very great number of unrelated person-to-person transactions. This sort of economy is based on the independent activities of a set of highly competitive commodity traders who relate to one another mainly by means of an incredible volume of ad hoc acts of exchange. ${ }^{2}$

The main distinction between the two sectors is that the firmcentred sector is capital intensive whereas the bazaar sector is labour intensive. Another significant distinction is that the former is, by organisation and character, sedentary, while the latter is mobile. By definition, mobility in the bazaar sector is a mark of differentiation that distinguishes it from its sedentary firm-centred counterpart. $^{3}$

Depending on the stage of economic development, a country can have both these components of the economy existing in equilibrium, or with one in decline and the other thriving. According to McGee's three-stage model, ${ }^{4}$ the third stage of the model will see the firm-type sector overriding the bazaar sector in an economy. Singapore has arrived at this 'third stage' as its bazaar sector is almost completely subordinated by the firm-type sector save for periodic staging of bazaar-sector retailing entities during festive holidays and/or for the purpose of attracting tourists.

The dichotomisation of the marketing system in Singapore into a firm-centred economy and a bazaar economy has been taking place since the earliest days when commerce began on the island..$^{5}$ The bazaar sector on the island is manifested in the form of travelling night markets or pasar malam, as they are locally and frequently called. The first travelling night market was set up in the early 1950s. In 1978, however, a ban was imposed on the travelling night markets, but in 1991 they made a comeback to the local marketing scene within public housing estates and have since been a common feature in public housing estates.

Over the last decade, an element from the firm-centred sector has become a common sight within public housing estates in Singapore. About 85 per cent of Singaporeans live in high-rise public housing estates. The standard and quality of public housing in Singapore has risen over the years, to the extent of reaching a standard close to that of the private housing estates. Over the years, many modern shopping centres have sprung up beside MRT stations in the suburban public housing estates. Northpoint shopping centre in Yishun New Town was the first such modern shopping centre to make inroads into the housing estates.

Hence, within the last decade, elements from both the firmcentred sector (suburban shopping centres) and the bazaar sector (pasar malam) are being introduced into public housing estates in Singapore. Given the two diametrically different sectors that 


\section{Development of night markets}

\section{Operation of night markets}

suburban shopping centres and pasar malam belong to, this research aims to investigate whether the various socio-economic backgrounds of shoppers have an effect on their perception of pasar malam and suburban shopping centres.

\section{THE DEVELOPMENT OF PASAR MALAM AND SUBURBAN SHOPPING CENTRES IN SINGAPORE}

Pasar malam or night markets are a form of retailing activity common to the South-East Asia region. This type of retailing activity is characterised by the mobile nature of the market/stalls, the linear alignment of stalls along streets and the occupation of private and public land for hawking which, ordinarily, is used for other purposes, such as the setting up of market/stalls in a public car park.

The first travelling night markets in Singapore were started in 1953 by a group of hawkers whose mode of operation had hitherto been associated with opera troupes and followed their itinerant performing schedules. ${ }^{6} \mathrm{Chao}^{7}$ noted that night markets were first started in areas where British servicemen and their families were present in large numbers.

The system of the travelling night markets is characterised by a week-long spatial temporal pattern in which markets are held on sites such as car parks and open spaces. Most hawkers never trade on the same site every night. Only where exceptionally favourable conditions prevail would markets be held on the same site more than once a week. The sites for the travelling night markets are selected entirely by individual hawkers.

Such regulated and constant change of operating locations is characteristic of the mobility found in the bazaar sector. It should be noted, however, that although market sites vary, the markets are run by basically the same group of hawkers.

The size of the night markets ranges from a congregation of less than ten stalls to over 200 stalls arranged linearly in one or more rows depending on the shape of the site. The peak trading period for the night markets stretches from about $6.30 \mathrm{pm}$ to $10.30 \mathrm{pm}$. Hawkers pay a licence fee to the local residents' committee managing the site or the district citizens' consultative committee on the basis of a unit pitch measuring 6 by 4 feet $(1.8$ by $1.2 \mathrm{~m})$, and one stall can occupy as many as four units. While most pasar malam hawkers are into full-time hawking, a great number of them also work in the day in other occupations.

The early growth of the night markets was slow. In 1960, however, there was a surge in the number of night markets; 1960 also marked the start of an era whereby night markets began to assume importance and popularity in the nightlife of Singapore City. During this time, the government adopted a light-handed approach towards such night markets which was limited to the licensing of hawkers, relocation of markets to ensure minimum traffic obstruction and policing of the market area. In all cases, the government stepped in only after the markets started to function. 
Ban on night markets

\section{Revitalisation of night markets}

\section{Development of suburban shopping centres}

The era of night markets being a popular activity came to an end, however, when a ban was imposed on them in 1978 due to growing public complaints of traffic congestion, noise, inconvenience and the potential problems of hygiene and sanitation posed by such activity.

In the 1980s, two attempts were made to revive the night market scene as a form of tourist attraction by the Sentosa Development Corporation and the Singapore Tourist Promotion Board, but they met with failure. The turning point for pasar malam came in 1991 when they made their way into housing estates and hawkers set up shop at void decks, walkways and other enclosed spaces selling clothes, fruit, toys, snacks such as steamed peanuts, foods such as Taiwanese sausages, tea, eggs and local delicacies, shoes, watches, compact discs, potted plants, mobile telephone accessories and other sundries.

This inroad of pasar malam into the housing estate heartland was originally conceptualised to revive older public housing estates, but over time it has become an easy and effective vehicle for grassroots organisations to raise much-needed funds for their community activities. This fund-raising capability of pasar malam has endeared them to grassroots organisations and thus contributed to their continued presence in public housing estates today.

Although pasar malam were revived in the 1990s, the process was not without changes. Today's pasar malam are heavily regulated by the authorities, whereas in the past the authorities adopted almost a 'hands-off' policy towards the night markets, especially with regard to the occupation of sites by the markets and the type of goods and services being sold.

As for the development of modern suburban shopping centres in Singapore, the 1990s saw 12 such centres making inroads into the heart of public housing estates within a span of eight years from 1992 to 1999. The impetus for such a surge in suburban shopping centre projects by developers is attributed in no small part to the 1991 Revised Concept Plan which aims to decentralise commercial activities to the suburbs. ${ }^{8}$ All these suburban shopping centres were developed by the private sector but are planned in that they are built on state land offered through the Housing and Development Board (HDB)'s sales of sites programme. Dale ${ }^{9}$ noted that the success of Northpoint shopping centre, which was the first modern suburban shopping centre, has created a formula of developing suburban shopping centres as part of the HDB's new town centres and in close proximity to MRT stations. Hence, suburban shopping centres that came up after Northpoint shopping centre were developed along this formula. These suburban shopping centres are usually four- to five-storeys high and their tenant mix usually includes a major department store, a supermarket, a food court, a multiplex cinema and speciality shops. Their aim is to provide a one-stop shopping experience, bringing shopping virtually to the doorsteps of residents in housing estates. 


\title{
Sequential mixed
method \\ Sequential mixed
method
}

\section{In-depth interviews}

\section{Questionnaire}

\author{
In-depth interviews
}


This research adopted a sample size of 500, which is good enough to add a certain degree of robustness to the research. A personal door-to-door interviewing method was adopted by the researchers as the method of administering the questionnaires for the quantitative research. All in all, the researchers took six weeks in the months of November and December 2001 to complete the interviews with the aid of four helpers.

The interviews were conducted in the public housing estates of five areas in Singapore as demarcated by the Urban Redevelopment Authority of Singapore (URA) for its preparation of development guide plans (DGPs). The five areas as demarcated are the western area, the northern area, the north-eastern area, the eastern area and the central area. Jurong West, Woodlands, Yishun, Tampines and Bishan were the respective housing estates singled out for the interviews in each area. In total 100 questionnaires were administered in each housing estate.

\section{FINDINGS OF THE QUALITATIVE RESEARCH}

Table 1 lists the individual attributes for both pasar malam and suburban shopping centres in descending order in terms of the number of times they were mentioned by respondents in the qualitative research.

Generally, product-related attributes such as 'price level' and 'variety of goods' were mentioned frequently for pasar malam. Similarly, product-related attributes in the form of 'quality of goods' and 'variety of goods' were also mentioned frequently for suburban shopping centres. These attributes, coupled with those identified via the literature review, were adopted in the questionnaire for the quantitative phase (Table 2).

Table I: List of mentions of pasar malam and suburban shopping centre attributes

\begin{tabular}{lrrlrr}
\hline \multicolumn{1}{c}{ Pasar malam } & & & & Suburban shopping centre \\
\hline Attributes & No. & $\%$ & Attributes & No. & $\%$ \\
\hline Price level & 19 & 18.6 & Quality of goods & 20 & 12.9 \\
Variety of goods & 17 & 16.7 & Variety of goods & 19 & 14.3 \\
Crowd level & 12 & 11.8 & Entertainment facilities & 19 & 14.3 \\
Shopping temperature & 11 & 10.8 & Eating outlets/restaurants & 14 & 10.0 \\
Eating outlets/restaurants & 10 & 9.8 & Latest fashion/model & 14 & 10.0 \\
Ambience & 10 & 9.8 & Number of stores & 14 & 10.0 \\
Number of stalls & 7 & 6.9 & Service quality & 14 & 10.0 \\
Entertainment facilities & 4 & 3.9 & Shopping temperature & 9 & 8.6 \\
Service quality & 3 & 2.9 & Level of cleanliness & 6.4 \\
Noise level & 3 & 2.9 & Price level & 5 & 3.6 \\
Protection from weather & 3 & 2.9 & Ambience & 0 & 0 \\
Level of cleanliness & 3 & 2.9 & Crowd level & 0 & 0 \\
Latest fashion/model & 0 & 0 & Noise level & 0 & 0 \\
Quality of goods & 0 & 0 & Protection from weather & 0 & 0 \\
Total & 102 & 100 & Total & 140 & 100
\end{tabular}

Note: Listing is in descending order in terms of number of times the attributes were mentioned during the qualitative research phase. 
Mean score perception ratings

Paired sample $t$-tests

\section{FINDINGS OF QUANTITATIVE RESEARCH}

\section{Perception ratings of pasar malam and suburban shopping centres}

In the questionnaire, the respondents were asked to rate a list of 27 attributes pertaining to pasar malam and suburban shopping centres using a scale of ' 1 ' (very poor) to ' 5 ' (very good). Table 2 shows the mean score perception ratings of the 27 dimensions of pasar malam and suburban shopping centres. More than half (17) of the dimensions of the pasar malam fall in the 'poor' region of the scale, ie less than 3. The dimension 'ability to bargain' has the highest mean score, while the dimension 'an ideal place to spend the day' scored the least. Pasar malam recorded an overall mean score of 2.92. Hence, the respondents have an overall poor perception of pasar malam.

On the other hand, besides the variables 'availability of festive/ carnival atmosphere', 'availability of local snacks/desserts/food' and 'ability to bargain', the rest of the dimensions of the suburban shopping centre fall in the 'good' region of the scale. The dimension 'adequate protection from weather' has the highest mean score. Suburban shopping centres recorded an overall mean score of 3.66. Hence, respondents have an overall good perception of suburban shopping centres.

Paired sample $t$-tests were conducted to shed additional light on the differences in the perception ratings of respondents. This specifically aims to compare the mean scores of each dimension of pasar malam and suburban shopping centres.

Table 2 also highlights the comparative mean scores of dimensions that attained a higher mean score for suburban shopping centres than for pasar malam. On the other hand, Table 3 highlights the comparative mean scores of dimensions that attained a higher mean score for pasar malam than for suburban shopping centres.

The null hypothesis (Ho) is that there is no significant difference between the mean scores. On the other hand, the alternative hypothesis denotes that a significant difference exists between the mean scores.

From Table 2, suburban shopping centres recorded higher mean scores than pasar malam for 22 dimensions. For the dimension 'high service standard of sales staff', there is no significant difference in the mean scores of pasar malam and suburban shopping centres.

Table 3 shows that the pasar malam recorded higher mean scores than suburban shopping centres for five dimensions: 'ability to bargain', 'availability of local snacks/desserts/food', 'affordable prices of goods/services', 'availability of festive/carnival atmosphere' and 'adequate number of stalls/stores'. Out of these five dimensions, suburban shopping centres recorded mean scores in the 'poor' region of the Likert scale (less than 3) for dimensions relating to bargaining, local products and festive atmosphere. 
Table 2: Comparative mean scores (paired samples t-test) for dimensions with higher mean scores in suburban shopping centres than in pasar malam

\begin{tabular}{|c|c|c|c|}
\hline & \multicolumn{2}{|c|}{ Mean } & \multirow[t]{2}{*}{ Sig. } \\
\hline & $\begin{array}{l}\text { Suburban shopping } \\
\text { centre }\end{array}$ & Pasar malam & \\
\hline Adequate protection from weather & 4.33 & 2.26 & 0.000 \\
\hline Comfortable shopping temperature & 4.27 & 2.56 & 0.000 \\
\hline Acceptable level of cleanliness & 4.13 & 2.20 & 0.000 \\
\hline A wide variety of goods/services being sold & 4.01 & 3.25 & 0.000 \\
\hline Availability of eating outlets/restaurants & 4.00 & 1.92 & 0.000 \\
\hline Availability of entertainment facilities & 3.99 & 2.53 & 0.000 \\
\hline Reasonable crowd level & 3.98 & 2.91 & 0.000 \\
\hline Easy to find ways/directions to shops/stalls & 3.97 & 2.64 & 0.000 \\
\hline Availability of latest fashion/model & 3.97 & 2.64 & 0.000 \\
\hline Availability of high-quality goods/services & 3.89 & 2.71 & 0.000 \\
\hline An ideal place to spend the day & 3.89 & 1.89 & 0.000 \\
\hline Good after-sales service & 3.88 & 2.84 & 0.000 \\
\hline A place for a family outing & 3.88 & 3.06 & 0.000 \\
\hline Convenient and tidy layout of stores/stalls & 3.82 & 2.47 & 0.000 \\
\hline Ability to meet shopping needs all the time & 3.80 & 2.14 & 0.000 \\
\hline Availability of adequate parking spaces & 3.78 & 2.68 & 0.000 \\
\hline Designs of stores/stalls are appealing & 3.70 & 2.51 & 0.000 \\
\hline High service standard of sales staff & 3.70 & 3.63 & - \\
\hline Reasonable noise level & 3.62 & 2.78 & 0.000 \\
\hline Ease of travel to shopping destination & 3.62 & 3.17 & 0.000 \\
\hline A substitute for downtown shopping & 3.59 & 1.98 & 0.000 \\
\hline Comfort of travel to shopping destination & 3.57 & 3.44 & 0.000 \\
\hline
\end{tabular}

\section{Hypothesis testing}

\section{Results of independent sample $t$-tests and ANOVA on shoppers' mean perception ratings of pasar malam and suburban shopping centres}

This section presents the results of hypothesis testing via the independent samples $t$-tests and analysis of variance (ANOVA) to analyse the effects of the various socioeconomic groups on the mean perception ratings of the respondents (see Table 2). Please refer to the Appendix for details of the independent samples $t$-tests and ANOVA.

\section{Pasar malam}

Table 4 shows that the male respondents have higher perceptions of pasar malam than female respondents for atmosphere, store, price and needs-related attributes. On the other hand, female respondents

Table 3: Comparative mean scores (paired samples t-test) for dimensions with higher mean scores in pasar malam than in suburban shopping centres

\begin{tabular}{lccc}
\hline & \multicolumn{2}{c}{ Mean } & Sig. \\
\cline { 2 - 3 } & Pasar malam & $\begin{array}{c}\text { Suburban shopping } \\
\text { centre }\end{array}$ \\
\hline Ability to bargain & 4.33 & 1.63 & 0.000 \\
Availability of local snacks/desserts/food & 4.31 & 2.40 & 0.000 \\
Affordable prices of goods/services & 4.17 & 3.25 & 0.000 \\
Availability of festive/carnival atmosphere & 4.02 & 2.56 & 0.000 \\
Adequate number of stalls/stores & 3.85 & 3.71 & 0.000
\end{tabular}




\section{Socioeconomic characteristics}

\section{No significant differences}

\section{Qualitative and quantitative research}

rated pasar malam higher than male respondents for travel, service and ancillary-facilities-related dimensions.

For the variable 'age', old and middle-aged respondents have higher mean scores than young respondents for a large number of pasar malam dimensions. Relating to the variables 'marital status' and 'educational level', respondents who are married and have nontertiary education recorded higher perceptions for pasar malam for more than half of the attributes.

Together, low-skilled respondents and homemakers rated highly more than two-thirds of the dimensions of pasar malam for the variable 'occupation'. Relating to the variable 'monthly income', low- and middle-income respondents recorded higher ratings for a majority of the dimensions.

Respondents who own a car have higher mean scores for most of the dimensions than those who do not own a car. Respondents who do not own a car recorded higher perceptions of pasar malam for dimensions relating to layout, protection from weather, comfort of travel and adequate parking spaces.

\section{Suburban shopping centres}

The majority of the statistical results recorded no significant differences among the means of the different groups of socioeconomic characteristics. More than half of the dimensions relating to the variable 'gender' recorded no significant differences in the mean scores among males and females. Male respondents rated suburban shopping centres higher for the number of stores, service standard and ability to meet shopping needs.

Relating to the variable 'marital status', singles have higher perceptions for suburban shopping centres relating to the dimension 'affordable prices of goods/services'. For the variable 'educational level', non-tertiary-educated respondents recorded higher mean scores for the dimension relating to variety of goods/services. Homemakers recorded higher mean scores than all other occupations for the dimension 'a place for a family outing'. Noncar owners rated the dimension 'affordable prices of goods/services' higher than car owners. All the dimensions relating to the variables 'age' and 'monthly income' recorded no significant difference in the mean scores among the subgroups.

\section{CONCLUSION AND IMPLICATIONS}

Using both qualitative and quantitative research, this study has provided an insight into shoppers' perceptions of pasar malam and suburban shopping centres. The study has shown that the suburban shopping centres recorded higher ratings for many of the dimensions relative to the pasar malam. The pasar malam were rated significantly higher for the 'ability to bargain', 'availability of local snacks/desserts/food', 'affordable prices of goods/services' and 'availability of festive/carnival atmosphere'. These aspects of the pasar malam should be further enhanced to position pasar malam differently from the suburban centres. 
Table 4: Summary of independent samples t-tests and ANOVA for pasar malam

\begin{tabular}{|c|c|c|c|c|c|c|c|}
\hline Dimension & Gender & Age & $\begin{array}{l}\text { Marital } \\
\text { status }\end{array}$ & $\begin{array}{l}\text { Educational } \\
\text { level }\end{array}$ & Occupation & $\begin{array}{l}\text { Monthly } \\
\text { income }\end{array}$ & Car \\
\hline Availability of festive/carnival atmosphere & - & M & $\mathrm{m}$ & $\mathrm{T}$ & $\mathrm{L}$ & M & - \\
\hline Reasonable crowd level & - & Y & - & $\mathrm{T}$ & $\mathrm{O}$ & M & - \\
\hline Reasonable noise level & $\mathrm{F}$ & M & $\mathrm{m}$ & $\mathrm{N}$ & $\mathrm{L}$ & - & Y \\
\hline Comfortable shopping temperature & M & $\mathrm{O}$ & - & $\mathrm{T}$ & $\mathrm{L}$ & $\mathrm{L}$ & Y \\
\hline Acceptable level of cleanliness & M & O & - & $\mathrm{N}$ & $\mathrm{HM}$ & $\mathrm{L}$ & - \\
\hline Convenient and tidy layout of stores/stalls & - & - & $\mathrm{m}$ & - & - & - & $\mathrm{N}$ \\
\hline Easy to find ways/directions to shops/stalls & - & Y & $S$ & $\mathrm{~T}$ & $\mathrm{O}$ & $\mathrm{L}$ & Y \\
\hline Adequate number of stalls/stores & M & $\mathrm{O}$ & M & $\mathrm{N}$ & $\mathrm{L}$ & M & - \\
\hline Designs of stores/stalls are appealing & M & $\mathrm{O}$ & M & $\mathrm{N}$ & $\mathrm{H}$ & $\mathrm{L}$ & Y \\
\hline A wide variety of goods/services being sold & - & Y & M & $\mathrm{N}$ & $\mathrm{HM}$ & M & Y \\
\hline Adequate protection from weather & M & O & M & $\mathrm{N}$ & $\mathrm{H}$ & M & $\mathrm{N}$ \\
\hline Comfort of travel to shopping destination & $\mathrm{F}$ & M & M & $\mathrm{N}$ & $\mathrm{L}$ & M & $\mathrm{N}$ \\
\hline Ease of travel to shopping destination & $\mathrm{F}$ & M & M & $\mathrm{N}$ & $\mathrm{L}$ & $\mathrm{L}$ & - \\
\hline Availability of adequate parking spaces & $\mathrm{F}$ & $\mathrm{O}$ & - & $\mathrm{N}$ & HM & $\mathrm{L}$ & $\mathrm{N}$ \\
\hline High service standard of sales staff & $\mathrm{F}$ & M & - & $\mathrm{T}$ & $\mathrm{L}$ & M & Y \\
\hline Good after-sales service & - & M & - & $\mathrm{T}$ & $\mathrm{H}$ & M & - \\
\hline Affordable prices of goods/services & M & M & M & $\mathrm{n}$ & HM & M & - \\
\hline Ability to bargain & M & O & M & $\mathrm{N}$ & $\mathrm{L}$ & $\mathrm{L}$ & Y \\
\hline Availability of high-quality goods/services & - & $\mathrm{O}$ & M & $\mathrm{N}$ & $\mathrm{HM}$ & $\mathrm{L}$ & - \\
\hline Availability of latest fashion/model & - & M & M & $\mathrm{N}$ & $\mathrm{L}$ & - & Y \\
\hline Ability to meet shopping needs all the time & M & $\mathrm{O}$ & M & $\mathrm{N}$ & $\mathrm{L}$ & $\mathrm{L}$ & - \\
\hline A substitute for downtown shopping & M & $\mathrm{O}$ & $\mathrm{n}$ & $\mathrm{N}$ & $\mathrm{L}$ & M & Y \\
\hline A place for a family outing & - & M & M & $\mathrm{N}$ & $\mathrm{L}$ & $\mathrm{L}$ & $\mathrm{n}$ \\
\hline Availability of local snacks/desserts/food & - & $\mathrm{Y}$ & M & $\mathrm{T}$ & $\mathrm{L}$ & $\mathrm{L}$ & - \\
\hline Availability of entertainment facilities & $\mathrm{F}$ & $\mathrm{O}$ & - & - & $\mathrm{L}$ & $\mathrm{L}$ & - \\
\hline Availability of eating outlets/restaurants & $\mathrm{F}$ & M & M & - & $\mathrm{HM}$ & M & y \\
\hline An ideal place to spend the day & M & O & M & $\mathrm{N}$ & $\mathrm{L}$ & M & Y \\
\hline
\end{tabular}

\section{Notes}

Gender (M/F): greater among males/females ( $t$-tests)

Age (Y/M/O): greater among young/middle-aged/old respondents (ANOVA)

Marital status $(\mathrm{S} / \mathrm{M})$ : greater among singles/married (t-test)

Educational level $(\mathrm{N} / \mathrm{T})$ : greater among non-tertiary/tertiary-educated respondents (ANOVA)

Occupation (L/M/H/HM/O): greater among lower/middle/higher occupation groups/homemaker/others (ANOVA)

Monthly income $(\mathrm{L} / \mathrm{M} / \mathrm{H})$ : greater among lower/middle/higher income (ANOVA)

$\operatorname{Car}(\mathrm{Y} / \mathrm{N})$ : greater among owners/non-owners (t-test)

Significance level: capital letters indicate: $p<0.05$; lower-case letter indicates: $p<0.10$; not significant is indicated by - .

\section{Create own niches}

Although both the pasar malam and the suburban shopping centre co-exist in the suburban housing estate, they have their very own niches that attract different shoppers to patronise them respectively. Incidentally, the factors which create the niches are consistent with the classical marketing price/product/place triangle for retail development. Many studies as far back as those in the 1960s, such as Huff ${ }^{16}$ and Berry, ${ }^{17}$ and thereafter Arnold et al. ${ }^{18}$ Nevin and Huston ${ }^{19}$ and Bell, ${ }^{20}$ have confirmed the significance of these factors for the success of any retail development. Similarly, in this study the pasar malam has strength in affordable prices through bargaining, local snacks/desserts/food and the festive/ carnival atmosphere. On the other hand, the suburban shopping centre is preferred for its comfortable and protected atmosphere, wide variety and quality of products and services.

The different attributes of the pasar malam and suburban shopping centres are likely to attract shoppers with different 
Table 5: Summary of independent samples t-tests and ANOVA for suburban shopping centres

\begin{tabular}{|c|c|c|c|c|c|c|c|}
\hline Dimension & Gender & Age & $\begin{array}{l}\text { Marital } \\
\text { status }\end{array}$ & $\begin{array}{l}\text { Educational } \\
\text { level }\end{array}$ & Occupation & $\begin{array}{l}\text { Monthly } \\
\text { income }\end{array}$ & Car \\
\hline Availability of festive/carnival atmosphere & - & - & - & - & - & - & - \\
\hline Reasonable crowd level & - & - & - & $\mathrm{t}$ & - & - & - \\
\hline Reasonable noise level & - & - & - & $\mathrm{t}$ & - & - & - \\
\hline Comfortable shopping temperature & $\mathrm{m}$ & - & - & - & - & - & - \\
\hline Acceptable level of cleanliness & $f$ & - & - & - & - & - & - \\
\hline Convenient and tidy layout of stores/stalls & - & - & - & - & - & - & y \\
\hline Easy to find ways/directions to shops/stalls & - & - & - & - & - & - & - \\
\hline Adequate number of stalls/stores & M & - & - & - & - & - & - \\
\hline Designs of stores/stalls are appealing & - & - & - & - & - & - & - \\
\hline A wide variety of goods/services being sold & $\mathrm{m}$ & - & - & $\mathrm{N}$ & - & - & - \\
\hline Adequate protection from weather & - & - & - & - & - & - & - \\
\hline Comfort of travel to shopping destination & - & - & - & - & - & - & - \\
\hline Ease of travel to shopping destination & $\mathrm{f}$ & - & - & - & - & - & - \\
\hline Availability of adequate parking spaces & - & - & - & - & - & - & - \\
\hline High service standard of sales staff & M & - & - & - & 1 & - & $n$ \\
\hline Good after-sales service & - & - & - & - & - & - & - \\
\hline Affordable prices of goods/services & - & $\mathrm{m}$ & $\mathrm{s}$ & - & - & - & $\mathrm{N}$ \\
\hline Ability to bargain & - & - & - & - & - & - & - \\
\hline Availability of high-quality goods/services & - & - & - & - & - & - & - \\
\hline Availability of latest fashion/model & - & - & - & - & - & - & - \\
\hline Ability to meet shopping needs all the time & M & - & - & - & - & - & - \\
\hline A substitute for downtown shopping & - & - & - & - & - & - & - \\
\hline A place for a family outing & - & - & - & - & HM & - & - \\
\hline Availability of local snacks/desserts/food & - & - & - & - & - & - & - \\
\hline Availability of entertainment facilities & - & - & - & - & - & - & - \\
\hline Availability of eating outlets/restaurants & - & - & - & - & - & - & - \\
\hline An ideal place to spend the day & - & - & - & - & - & - & - \\
\hline
\end{tabular}

Notes

Gender (M/F): greater among males/females ( $t$-tests)

Age (Y/M/O): greater among young/middle-aged/old respondents (ANOVA)

Marital status $(\mathrm{S} / \mathrm{M})$ : greater among singles/married (t-test)

Educational level $(\mathrm{N} / \mathrm{T}$ ): greater among non-tertiary/tertiary-educated respondents (ANOVA)

Occupation (L/M/H/HM/O): greater among lower/middle/higher occupation groups/homemaker/others (ANOVA)

Monthly income (L/M/H): greater among lower/middle/higher income (ANOVA)

$\operatorname{Car}(\mathrm{Y} / \mathrm{N})$ : greater among owners/non-owners (t-test)

Significance level: capital letters indicate: $p<0.05$; lower-case letter indicates: $p<0.10$; not significant is indicated by -

\section{Impact of socioeconomic characteristics}

\section{Price-related attributes}

profiles. Through the independent samples $t$ and ANOVA tests, it is shown that the different socioeconomic characteristics of respondents have an impact on their perceptions of pasar malam and suburban shopping centres. Suburban shopping centres recorded relatively smaller significant differences among the respondents from the different socioeconomic backgrounds, however.

In general, the research has shown that price-related attributes recorded high ratings among respondents who are single, and with a growing number of singles among Singaporeans, shopping centre management would do well to offer goods and services which are within the comfortable spending level of singles if they are to tap into the growing singles market.

The research has shown that respondents with one or more of the characteristics of being old and middle-aged, married, non-tertiaryeducated, in low-skill occupations, homemakers and having low and middle income ranges generally perceive pasar malam in a 


\section{Profile of night- market shoppers}

\section{Need to understand local markets}

better light. Hence, pasar malam operators should consider bringing in stallholders who provide goods and services that meet the needs of such socioeconomic backgrounds as they are more likely to patronise pasar malam.

Respondents who have a low level of skills and are from low and middle income ranges rated highly most of the characteristics of pasar malam. This suggests that shoppers of such socioeconomic backgrounds take to pasar malam and in a way depend on them for a large part of their shopping needs. Hence, policy makers may consider the need to modify the licensing and other restrictive rules such as the duration and frequency of pasar malam in order to cater to the needs of such shoppers, especially during an economic downturn when wages are depressed and spending declines.

The attribute 'an ideal place to spend the day' is rated highly by old respondents for pasar malam. Hence, pasar malam qualify as places which the aged considered conducive to spending their time in. This may be due to the nostalgic feelings experienced by the aged as pasar malam were very popular back in the 1950s, 1960s and 1970s. Hence, policy makers may consider making pasar malam into places in which to engage the aged leisurely, mentally or even productively in addition to existing grassroots facilities and support for the aged so as better to promote active ageing.

The above findings show the different profiles of the shoppers and the link to their perceptions of different types of retail development. This infers that property developers and retailers need to have a better understanding of their local markets to develop an appropriate 'experience'/product mix to cater to the shoppers within the catchment area. While this study forms an initial attempt to understand the bazaar sector, more research should be carried out to enhance the bazaar sector as a retail form as well as to develop a niche for it to co-exist with the firm-centred sector.

\section{APPENDIX: DETAILS OF INDEPENDENT SAMPLES T-TESTS AND ANOVA}

The independent samples $t$-tests are used to determine if there is a statistically significant difference between two population means of independent samples. The independent samples $t$-tests will compare the two population means of independent samples by computing the $t$-value and its $p$-value (sig. (two-tailed)).

ANOVA is used to determine if there is a statistically significant difference between three or more groups of population means. ANOVA compares the means of the three or more groups by computing the $\mathrm{F}$ statistics and their significant value.

The null hypothesis (Ho) states that there is no significant difference in the means of the various groups of the respondents in the sample. On the other hand, the alternative hypothesis indicates that a significant difference exists in the means of the various groups of the respondents in the sample. The results of the hypothesis testing will be represented by the significance level 
indicated in Table 4. In this section, $p$-values greater than 0.100 are reported as not significant; in such cases the probability that the difference is a result of pure chance is greater than 10 per cent. Where $p$-values fall within the range of $0.100-0.050$ they should be treated with caution. For the purpose of interpretation, a $p$-value of 0.05 will be used as a benchmark.

The respective dimensions of pasar malam and suburban shopping centres are tested against the subgroups of seven socioeconomic variables. The results of the $t$-test and ANOVA for pasar malam and suburban shopping centres are shown in Tables 4 and 5 respectively. Essentially, the tables indicate the subgroups in each of the socioeconomic variables that have a greater mean score and their respective level of significance.

The subgroups of the socioeconomic variables have been abbreviated to facilitate the tabulation of the results. Table 6 shows the labelling of the subgroups of all the variables.

Table 6: Subgroups of the socio-economic variables

\begin{tabular}{lll}
\hline Variable & Subgroups & Abbreviation \\
\hline Gender & Male & M \\
Age & Female & F \\
& Young & Y \\
Marital status & Middle-aged & M \\
& Old & O \\
Educational level & Single & S \\
& Married & M \\
Occupation & Non-tertiary & N \\
& Tertiary & T \\
& Low & L \\
& Middle & M \\
Monthly income & High & H \\
& Homemaker & HM \\
Car ownership & Others & O \\
& Low & L \\
& Middle & M \\
& High & H \\
& Yes & Y \\
\hline
\end{tabular}

\section{References}

1. Geertz, C. (1963) Peddlers and Princes, University of Chicago, Chicago Il, pp. 28-29.

2. Ibid.

3. Yeung, Y. M. (1973) National Development Policy and Urban Transformation in Singapore: A Study of Public Housing and the Marketing System, Research Paper No. 149, Department of Geography, University of Chicago, Chicago, IL.

4. McGee, T. G. (1970) Hawkers in Selected Asian Cities: A Preliminary Investigation, Centre of Asian Studies, University of Hong Kong, Hong Kong.

5. Yeung, ref. 3 above.

6. Ibid.

7. Chao, S. K. (1962) 'The phenomenon of traveling night market: A study of its origin, growth and organization', unpublished thesis, Department of Social Work, University of Singapore. 
8. Urban Redevelopment Authority (2003) 'Land use and urban design planning: Development guide plans', Urban Redevelopment Authority, Singapore, www.ura.gov.sg.

9. Dale, O. J. (1999) Urban Planning in Singapore: The Transformation of a City, Oxford University Press, Singapore.

10. Malhotra, N. K. (1996) Marketing Research: An Applied Orientation, 2nd edition, Prentice-Hall, Englewood Cliffs, NJ.

11. Ibid.

12. Burgess, R. G. (1982) 'The unstructured interview as a conversation', in Burgess, R. G. (ed.) Field Research: A Sourcebook and Field Manual, George Allen and Unwin, London, pp. 107-110.

13. Walker, R. (1985) 'An introduction to applied qualitative research', in Walker, R. (ed.) Applied Qualitative Research, Gower Publishing, Brookfield; Vermont, pp. 3-26.

14. Ibrahim, M. F. and McGoldrick, P. J. (2003) Shopping Choices with Public Transport Options: An Agenda for the 21st Century, Ashgate, Aldershot, England.

15. Malhotra, ref. 10 above.

16. Huff, D. L. (1960) 'A topographical model of consumer space preference', Papers and Proceedings of the Regional Science Association, Vol. 6, pp. 159-174.

17. Berry, L. L. (1969) 'The components of department store image: A theoretical and empirical analysis', Journal of Retailing, Vol. 45, No. 1, pp. 3-20.

18. Arnold, S. J., Ma, S. and Tigert, D. J. (1978) 'A comparative analysis of determinant attributes in retail store selection', Advances in Consumer Research, Vol. 5, No. 1, pp. 663-667.

19. Nevin, J. R. and Huston, M. J. (1980) 'Image as a component of attraction to intraurban shopping areas', Journal of Retailing, Vol. 56, No. 1, pp. 77-93.

20. Bell, S. J. (1999) 'Image and consumer attraction to intraurban retail areas: An environmental psychology approach', Journal of Retailing and Consumer Services, Vol. 6, No. 2, pp. 67-78. 